\title{
Muscidae (Diptera) of medico-legal importance associated with ephemeral organic substrates in seasonally dry tropical forests
}

\author{
Taciano Moura Barbosa, ${ }^{1,2}$ \& Simão Dias Vasconcelos ${ }^{1,3}$ \\ 1 Universidade Federal de Pernambuco (UFPE), Centro de Biociências (CB), Departamento de Zoologia. Recife, PE, Brasil. \\ 2 E-mail: tacianomoura7@gmail.com \\ 3 ORCID: 0000-0002-8722-0836. E-mail: simaovasconcelos@yahoo.com.br
}

\begin{abstract}
Muscidae (Diptera) comprises one of the most important taxa in medical, veterinary and forensic entomology, especially due to their association with decomposing carcasses and cadavers. Yet, knowledge on their distribution and behaviour is still incipient in several biomes, which is the case of dry tropical forests. This study aimed to evaluate the attractiveness of different organic substrates to species of Muscidae in areas of seasonally dry forests (Caatinga) in Northern Brazil. Sampling was carried out in five Caatinga areas between 2015 and 2017, using suspended traps baited with bovine spleen, fish or human faeces. When all samplings were combined, 3,176 adults of nine species were collected. The assemblages of muscids had higher richness and abundances on bovine spleen, which attracted $66 \%$ of all specimens, when compared to the other substrates. Musca domestica was the most abundant species, and it was dominant in assemblages associated with spleen and fish. Assemblages attracted to spleen and fish had higher similarity, differing from those associated with faeces. Differences in food attractiveness are presented for species of medical interest as pathogen vectors (e.g., Synthesiomyia nudiseta (Wulp, 1883)) and of forensic relevance as colonizers of human corpses (e.g., Ophyra aenescens (Wiedemann, 1830)).
\end{abstract}

Key-Words. Atherigona orientalis; Caatinga; Carrion; Forensic entomology; Synthesiomyia nudiseta.

\section{INTRODUCTION}

Muscidae (Diptera) comprises one of the most important taxa in medical, veterinary and forensic entomology (Skidmore, 1985; Grzywacz et al., 2017). Yet, knowledge on their distribution and behaviour is still incipient in several biomes, which is the case of dry tropical forests (DTF), a complex set of environments that cover over one million $\mathrm{km}^{2}$ in Africa, Americas, Asia and Oceania (Miles et al., 2006). In broad terms, DTF's are characterized by limited and irregular rainfall, high temperature throughout the year, low air and soil humidity and a set of specializations of local fauna and flora to adapt to xeric conditions (Bullock et al., 1995). Sudden shifts in resource availability in dry forests, regulated mostly by pulses in water availability, act as a selective force that favours insects that can promptly locate and colonize patchy substrates, such as carrion.

Dry tropical forests are among the most threatened environments in the world due to climate change, deforestation, fire and conversion to agriculture, particularly in Brazil (Miles et al., 2006; Santos et al., 2011). The Brazilian seasonally dry tropical forest (SDTF), known as Caatinga, covers ca. $800,000 \mathrm{~km}^{2}$ and it is exposed to severe droughts that can last decades. It is the least studied biome in the Neotropics (Santos et al., 2011), which encourages research on insect diversity and behaviour in order to understand the dynamics of assemblages in patchy, ephemeral resources.

Besides their ecological role in nutrient cycling, Muscidae species can act as vectors of helminths, bacteria and viruses (e.g., Synthesiomyia nudiseta (Wulp, 1883)), cause myiasis (e.g., Musca domestica L., 1758) and feed on livestock (e.g., Stomoxys calcitrans Linnaeus, 1758) (Skidmore, 1985). Additionally, several species, such as Ophyra aenescens (Wiedemann, 1830), colonize human cadavers and have increasing forensic relevance in criminal investigations (Grzywacz et al., 2017). For instance, the presence of puparia and adult fragments of Ophyra capensis (Wiedemann, 1818) in the oesophagus of a mummy from the early XIX century helped to reconstitute the post-mortem conditions (Couri et al., 2009).

In this study, we performed a short-term survey of Muscidae species associated with decomposing substrates in fragments of SDTF. Specifically, we aimed to compare the attractiveness of different baits to muscids, with emphasis on species of medico-legal importance.

\section{MATERIALS AND METHODS}

Field experiments were performed in five fragments of SDTF in the states of Paraiba and Pernambuco, Northeastern Brazil, separated from 
one another by at least $100 \mathrm{~km}$, in the municipalities of Afogados da Ingazeira (lat $07^{\circ} 45^{\prime} 03^{\prime \prime}$, long $37^{\circ} 38^{\prime} 20^{\prime \prime} \mathrm{W}$ ), Buíque (lat $08^{\circ} 29^{\prime} 56^{\prime \prime} \mathrm{S}$, long $37^{\circ} 22^{\prime} 14^{\prime \prime} \mathrm{W}$ ), Betânia (lat $08^{\circ} 16^{\prime} 29^{\prime \prime} \mathrm{S}$, long $38^{\circ} 02^{\prime} 03^{\prime \prime} \mathrm{W}$ ), Petrolina (lat 09²3'39"S, long $40^{\circ} 30^{\prime} 35^{\prime \prime} \mathrm{W}$ ) and Boqueirão (lat $08^{\circ} 25^{\prime} 35^{\prime \prime} \mathrm{S}$, long $36^{\circ} 08^{\prime} 06^{\prime \prime} \mathrm{W}$ ) (Fig. 1). To maximize collection, sampling was performed always in the rainy season in all fragments, and each area was sampled twice. During the three-year study, insect collection was performed in 2015 and 2016 in Buíque, Betânia and Petrolina, while the SDTF fragments in Afogados da Ingazeira and Boqueirão were sampled in 2016 and 2017. Despite intrinsic variations, vegetation in all fragments consists mostly of shrub native species, with predominance of Cactaceae, and sparsely distributed trees such as the native Ziziphus joazeiro (Rhamnaceae), Spondias tuberosa (Anacardiaceae) and the introduced Prosopis juliflora (Leguminosae). Vertebrate fauna comprises mostly small to medium-sized species of mammals, reptiles and birds, whose population can diminish considerably in the dry periods.

Adult flies were collected using traps described by Oliveira et al. (2016), a low-cost device that relies on olfactory cues and positive phototropism. The traps were suspended $1.0 \mathrm{~m}$ above the soil and contained decomposing matter as bait ( $150 \mathrm{~g}$, after $48 \mathrm{~h}$ exposure to $25^{\circ} \mathrm{C}$ ). Three types of baits were used: bovine spleen, fish (sardine) and human faeces. Sixteen traps of each treatment separated from one another by $25 \mathrm{~m}$ were exposed in the field for $48 \mathrm{~h}$ in each environment, after which all traps were taken to the laboratory and adults were identified (Carvalho et al., 2002).
The assemblage of Muscidae associated with each substrate was characterized by: richness, relative frequency, Shannon-Wiener's diversity index, Simpson's dominance and Pielou's equity index, while abundance was compared using a Chi-square test (minimum of 100 adults/treatment). To test for similarities in the assemblages on each bait, we built a similarity matrix, through the index of Bray Curtis, after data transformation log $(x$ $+1)$. The statistical packages Primer 5.0 and Biostat 5.0 were used, with $5 \%$ significance level.

\section{RESULTS}

When all samplings were combined, 3,176 adults of nine species were collected (Table 1). Overall, the most abundant species were $M$. domestica, Atherigona orientalis Schiner, 1868 and S. nudiseta, corresponding to $64.0 \%$, $18.3 \%$ and $12.6 \%$ of all specimens, respectively. Insect abundance differed between treatments $\left(X^{2}=52.39\right.$; d.f. $=2 ; P<0.01$ ), as spleen was associated with the highest number of flies ( $66.0 \%$ of total). Higher abundance on spleen was observed for $M$. domestica and $A$. orientalis, while faeces were the most attractive substrate to S. nudiseta (Table 1). The number of female adults was significantly higher than their male counterparts for all species in all substrates $(P<0.0001)$ (Fig. 2).

Diversity indices ranged from 0.86 (spleen) to 1.16 (fish) and dominance varied from 0.39 (fish) to 0.50 (spleen), which is explained by the numerical dominance (73.2\%) of $M$. domestica on spleen. Equity indices varied from 0.41 (spleen) to 0.68 (fish), showing higher unifor-

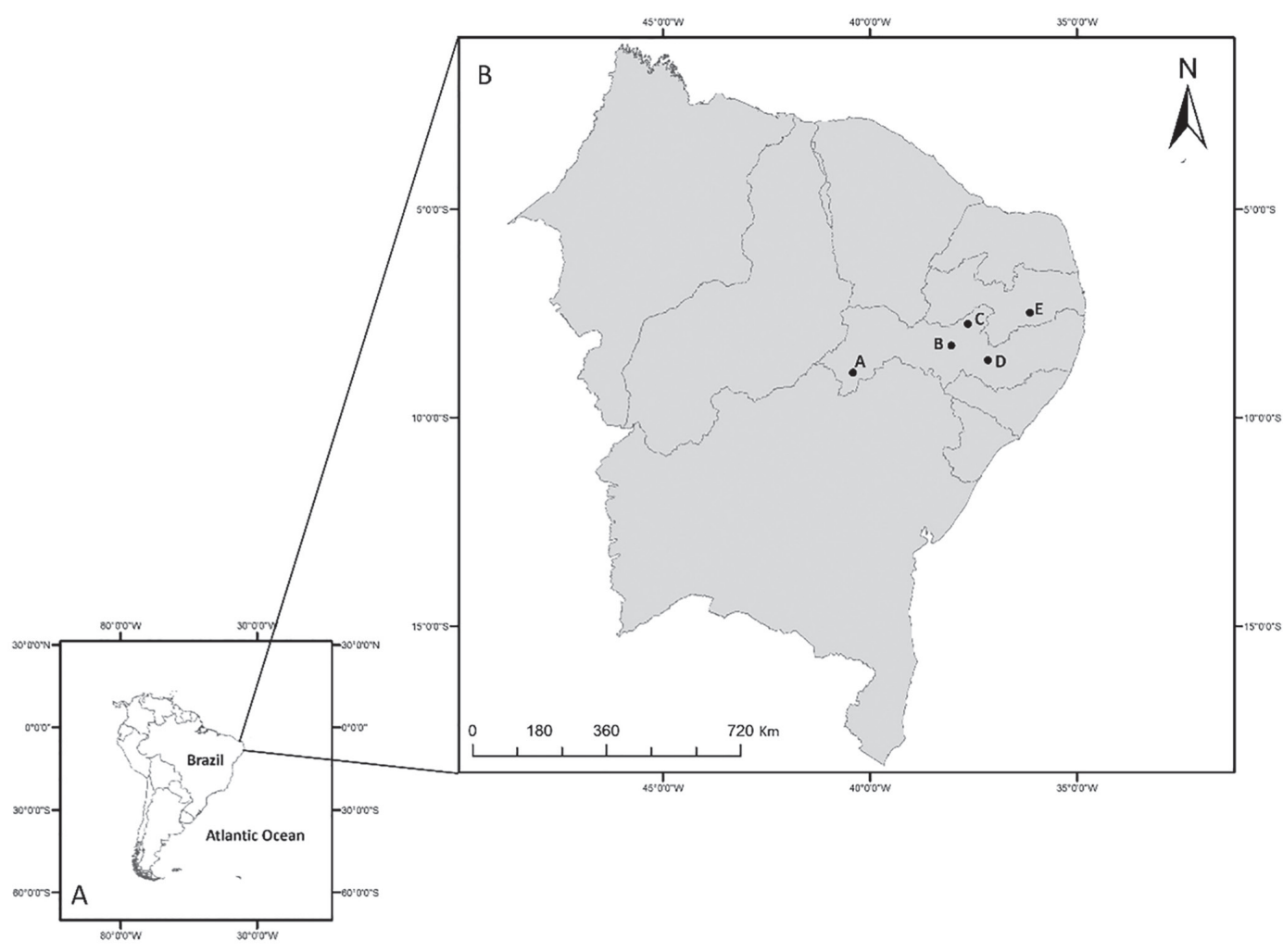

Figure 1. Location of sample sites along the seasonally dry tropical forest (Caatinga) in Northeastern Brazil. (A) Petrolina; (B) Betânia; (C) Afogados da Ingazeira; (D) Buíque; (E) Boqueirão. 
Table 1. Abundance and relative frequency (\%) of Muscidae species registered on three types of bait in fragments of seasonally dry forests in Brazil.

\begin{tabular}{|c|c|c|c|c|c|c|c|}
\hline \multirow{2}{*}{ Species } & \multicolumn{2}{|c|}{ Spleen } & \multicolumn{2}{|c|}{ Fish } & \multicolumn{2}{|c|}{ Faeces } & \multirow{2}{*}{ Total } \\
\hline & $\mathbf{N}$ & $\%$ & $\mathrm{~N}$ & $\%$ & $\mathrm{~N}$ & $\%$ & \\
\hline Atherigona orientalis & 350 & 16.57 & 155 & 20.58 & 76 & 24.44 & 581 \\
\hline Atherigona sp. & 33 & 1.56 & 81 & 10.76 & 1 & 0.32 & 115 \\
\hline Gymnodia debilis & 4 & 0.19 & - & - & 2 & 0.64 & 6 \\
\hline Graphomya maculata & 6 & 0.28 & - & - & - & - & 6 \\
\hline Graphomya sp. & - & - & - & - & 2 & 0.64 & 2 \\
\hline Musca domestica & 1,546 & 73.20 & 436 & 57.90 & 50 & 16.08 & 2,032 \\
\hline Ophyra aenescens & 24 & 1.14 & 7 & 0.93 & - & - & 31 \\
\hline Ophyra chalcogaster & 1 & 0.05 & 2 & 0.27 & - & - & 3 \\
\hline Synthesiomyia nudiseta & 148 & 7.01 & 72 & 9.56 & 180 & 57.88 & 400 \\
\hline Total & 2,112 & 100 & 753 & 100 & 311 & 100 & 3,176 \\
\hline
\end{tabular}

mity in the relative frequency of the species on the latter. Cluster analysis evidenced high similarity between muscid assemblages on spleen and fish (Fig. 3).

\section{DISCUSSION}

The number of species registered in this study did not differ much from other studies performed in rainforest fragments, urban areas and agroecosystems in South America (Vasconcelos \& Araujo, 2012) and was similar to that recorded in longer studies using large vertebrate carcasses as baits in fragments of seasonally dry tropical forests (Vasconcelos et al., 2016). This suggests that small baits can be surrogates for short-term field inventories of diversity of copronecrophagous Muscidae, without the ethical, logistical and economical restraints imposed by the use of animal carcasses.

The consumption of several types of decomposing substrates by Muscidae reported in the literature (Savage, 2002) is corroborated in this study, especially for $M$. domestica, $A$. orientalis and S. nudiset $a$, which are widely distributed and show adaptations to the harsh condition of the Caatinga (Carvalho, 2002). The high similarity of muscid assemblages associated with fish and spleen have been reported to occur in other environments such as rainforest and agroecosystems (Vasconcelos et al., 2015). Volatile organic compounds (VOC's) released by decomposing fish are thought to attract a high diversity of necrophagous dipterans of Muscidae and other families, including also Calliphoridae and Sarcophagidae (Carmo et al., 2017). Faeces, on the other hand, are nutritionally poorer than carcasses and tend to be used as food substrate for the development of fewer species (D'Almeida \& Almeida, 1998). According to Blackith \& Blackith (1993), flies visit faecal matter to oviposit, to gain water from fresh dung in dry climates, and to gain nourishment from the dissolved or finely particulate substances. This is critical in the Caatinga, where resources are short-lived and erratic. Considering the scarcity of large native mammals, goats raised in small-scale livestock tend to provide the main input of faecal matter.

The low attractiveness of faeces to $M$. domestica reported here diverges from previous records that suggest

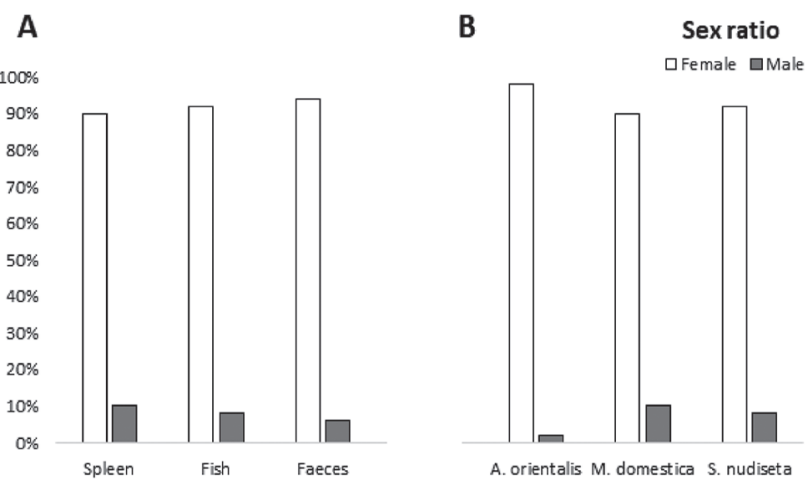

Figure 2. Sex ratio (female/male) of muscids collected in SDTF's fragments in Brazil, according to the type of bait (A) and species (B).

Group average Transform: Log $(X+1)$ B Curtis similarity
Resemblance: 17 Bray

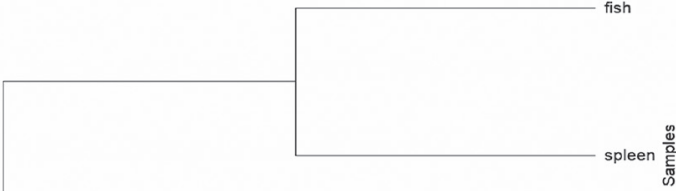

\begin{tabular}{rrrr}
1 & 1 & 1 & \multicolumn{8}{c}{$\begin{array}{c}10 \\
\text { Similarity }\end{array}$} & 90 & 100
\end{tabular}

Figure 3. Cluster analysis for the similarity between muscid assemblages, according to the type of bait.

strong colonization of faeces by this species (Greenberg, 1971). Although S. nudiseta have been frequently reported on fish carcasses (D'Almeida \& Almeida, 1998), this study reinforces the use of faecal matter as an alternative and/or complementary substrate. The overall low abundance of Ophyra aenescens and Ophyra chalcogaster (Wiedemann 1824) is probably due to their preference for large carcasses (Barbosa et al., 2009). A. orientalis was strongly attracted to animal baits in this study but it has also been shown to feed on decaying plant material (D'Almeida \& Almeida, 1998). Interestingly, the species is reported in association with carcasses in urban and forested areas (Barbosa et al., 2009; Vasconcelos et al., 2016).

Coprophagy is a common feeding habit of Gymnodia species (Uribe-M. et al., 2010) and it is confirmed for Gymnodia debilis (Williston 1896) in this study. The low abundance of $G$. debilis in the five dry forest fragments in Brazil may reflect a stronger association of the species with urban/modified environment. The low abundance of Graphomya maculata (Scopoli, 1763) may be due to the fact that its larvae often prey upon other dipteran larvae and adults are mostly flower feeders (Skidmore, 1985; Marques \& Couri, 2007). The numerical dominance of females found in the Caatinga has been a common pattern in surveys based on baits and carrion performed elsewhere (Mulieri et al., 2015; Carmo et al., 2017) and reflects the selection of the substrates for the development of the immature stages. Furthermore, the capture of few 
male specimens compromises the register of a few species of Muscidae whose identification depends on the examination of the male genitalia.

Data presented here contribute to expand the knowledge on the biogeography of Muscidae species, especially given the shortage of information on DTF's in the Americas and other continents. The unfavourable conditions of DTF's (e.g., severe drought) act as selective forces for the development of physiological traits to cope with water-stressed environments and ephemeral resources. In the case of coprophagies species, the scarcity of large vertebrates in the Caatinga further stimulates fierce competition for patchy resources.

The non-discriminatory feeding behaviour of S. nudiseta, M. domestica and $A$. orientalis and their synanthropy highlights their medical importance due to their role as mechanical vectors of pathogens and as causal agents of myiasis (Greenberg, 1971; Skidmore, 1985; Uribe-M. et al., 2010). Brazilian DTF's suffer a radical transformation caused by urbanization and intensive agriculture so that field surveys are crucial for the monitoring and control of species of medical and veterinary importance. Unsanitary conditions observed in many breeding systems are likely to maximize the potential of muscid in causing myiasis on goats in Caatinga fragments (Barbosa \& Vasconcelos, 2015).

Finally, according to Grzywacz et al. (2017), Muscidae have received relatively little attention in forensic field studies although they can colonize bodies in urban and forested areas, under sunny and shade conditions, in exposed and concealed situations. Recently, O. aenescens was found on the soil below a hanged cadaver in Northeastern Brazil (Vasconcelos et al., 2017), which suggests that the actual role of Muscidae in forensic entomology is far from being properly appraised. In this scenario, databases on species-habitat association may help in the evaluation of the potential of species as indicators of site of death.

\section{ACKNOWLEDGMENTS}

We thank Fundação de Amparo a Pesquisa do Estado de Pernambuco (FACEPE), Coordenação de Aperfeiçoamento de Pessoal de Nível Superior (CAPES) and Conselho Nacional de Desenvolvimento Científico e Tecnológico (CNPq) for financial support, the staff from the Insects of Forensic Importance Research Group for their invaluable help with insect collection and Instituto Chico Mendes de Conservação da Biodiversidade (ICMBio) for the licence for insect collection.

\section{REFERENCES}

Barbosa, R.R.; Mello-Patiu, C.A.; Mello, R.P. \& Queiroz, M.M.C. 2009. New records of calyptrate dipterans (Fanniidae, Muscidae and Sarcophagidae) associated with the decomposition of domestic pigs in Brazil. Memórias do Instituto Oswaldo Cruz, 104: 923-926.
Barbosa, T.M. \& VasconceloS, S.D. 2015. An updated checklist of myiasisinducing Diptera species in livestock in Northeastern Brazil. Archivos de Zootecnia, 64: 187-190.

Blackith, R.E. \& Blackith, R.M. 1993. Differential attraction of calyptrate flies (Diptera) to faeces, Journal of Natural History, 27: 645-655.

Bullock, S.H.; Mooney, H.A. \& Medina, E. 1995. Seasonally Dry Tropical Forests. Cambridge, Cambridge University Press. 450p.

Carmo, R.F.R.; Oliveira, D.L.; Barbosa, T.M.; Soares, T.F.; Souza, J.R.B. \& Vasconcelos, S.D. 2017. Visitors versus colonizers: An empirical study on the use of vertebrate carcasses by necrophagous Diptera in a rainforest fragment. Annals of the Entomological Society of America, 110: $492-500$.

Carvalho, C.J.B. 2002. Muscidae (Diptera) of the Neotropical Region: Taxonomy. Curitiba, Editora Universidade Federal do Paraná. 287p.

Couri, M.S.; Cunha, A.M.; Souza, S.M.F.M. \& Laeta, M. 2009. Ophyra capensis (Wiedemann) (Diptera, Muscidae) found inside the esophagus of a mummy in Lisbon (Portugal). Papéis Avulsos de Zoologia, 46: 87-91.

D’Almeida, J.M. \& Almeida, J.R. 1998. Nichos tróficos em dípteros caliptrados, no Rio de Janeiro, RJ. Revista Brasileira de Biologia, 58: 563-570.

Greenberg, B. 1971. Flies and Disease Vol. I, Ecology, Classification, and Biotic Association. Princeton, NJ, Princeton University Press. 586p.

Grzywacz, A.; Hall, M.J.R.; Pape, T. \& Szpila K. 2017. Muscidae (Diptera) of forensic importance an identification key to third instar larvae of the western Palaearctic region and a catalogue of the muscid carrion community. International Journal of Legal Medicine, 131: 855-866.

Marques, B. \& Couri, M. 2007. Taxonomia e morfologia de espécies neotropicais de Graphomya Robineau-Desvoidy (Diptera, Muscidae). Revista Brasileira de Entomologia, 51: 436-444.

Miles, L.; Newton, A.C.; Defries, R.S.; Ravilious, C.; May, I.; Blyth, S.; Kapos, V. \& Gordon, J.E. 2006. A global overview of the conservation status of tropical dry forests. Journal of Biogeography, 33: 491-505.

Mulieri, P.R.; Patitucci, L.D. \& Olea, M.S. 2015. Sex-biased patterns of saprophagous Calyptratae (Diptera) collected with different baits of animal origin. Journal of Medical Entomology, 52: 386-393.

Santos, J.C.; Leal, I.R.; Almeida-Cortez, J.S.; Fernandes, G.W. \& Tabarelli, M. 2011.Caatinga: the scientific negligence experienced by a dry tropical forest. Tropical Conservation Science, 4: 276-286.

Savage, J. 2002. Exploring the diversity of flies (Diptera). Cleaning up the world: Dipteran decomposers. Biodiversity, 3: 12-15.

Skidmore, P. 1985. The Biology of the Muscidae of World. Dordrecht, W. Junk Publishers. xiv+550p.

Uribe-M., N.; Wolff, M. \& Carvalho, C.J.B. 2010. Synanthropy and ecological aspects of Muscidae (Diptera) in a tropical dry forest ecosystem in Colombia. Revista Brasileira de Entomologia, 54: 462-470.

Vasconcelos, S.D. \& Araujo, M. 2012. Necrophagous species of Diptera and Coleoptera in Northeastern Brazil: state of the art and challenges for the forensic entomologist. Revista Brasileira de Entomologia, 56: 7-14.

Vasconcelos, S.D.; Barbosa, T.M. \& Oliveira, T.P.B. 2015. Diversity of forensically-important dipteran species in different environments in Northeastern Brazil, with notes on the attractiveness of animal baits. The Florida Entomologist, 98: 770-775.

Vasconcelos, S.D.; Costa, D.L. \& Oliveira, D.L. 2017. Entomological evidence in a case of a suicide victim by hanging: first collaboration between entomologist and forensic police in northeastern Brazil. Australian Journal of Forensic Science. DOI

Vasconcelos, S.D.; Salgado, R.L.; Barbosa, T.M. \& Souza, J.R.B. 2016. Diptera of medico-legal importance associated with pig carrion in a tropical dry forest. Journal of Medical Entomology, 53: 1131-1139. 